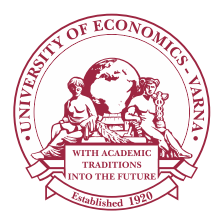

Izvestiya Journal of Varna University of Economics 2 (2021)

IZVEST IYA

Journal of Varna University of Economics

http://journal.ue-varna.bg

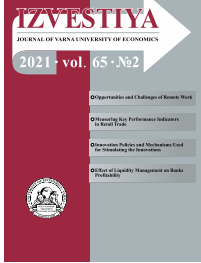

\title{
ESTIMATING THE DETERMINANTS OF FOOD IMPORT DEMAND IN AFRICA
}

\section{Saada Abba ABDULLAHI ${ }^{1}$}

${ }^{1}$ Department of Economics, Baze University Abuja, Nigeria.

E-mail: saada.abdullahi@bazeuniversity.edu.ng

\section{JEL: Q17, Q18, Q11, D0 Abstract}

This paper examines the determinants of food import demand in Africa taking the case of Nigeria using the ARDL bounds testing approach. Specifically, the study aims to estimates the short run and long run price and income elasticities of food import demand in Nigeria. The paper used annual time series data over the period 1981 to 2019. The empirical result indicates the existence of a long run equilibrium relationship between food import demand and its determinants. The long run price and income elasticities are $-4.57 \%$ and $5.57 \%$, respectively. The result shows that population and food production exert significant influence

Key words:

Food, Import Demand, Trade Elasticities, ARDL bounds test, Nigeria in determining food import demand in both the short run and long run while exchange rate is insignificant in the long run. The paper recommends that price and income-oriented policies will be effective measures in controlling food import demand in Nigeria.

(C) 2021 University of Economics - Varna

Citation: ABDULLAHI, Saada Abba. Estimating the Determinants of Food Import Demand in Africa. Izvestiya Journal of Varna University of Economics, 65 (2), pp. 238- 252.

DOI: 10.36997/IJUEV2021.65.2.238

\section{Introduction}

Nigeria is Africa's largest economy with estimated gross domestic product (GDP) of about $\$ 397.30$ billion and has the largest population of 195.87 billion in 2018 (NBS, 2018). It is also Africa's largest producer and exporter of oil and has the largest natural gas reserve in the continent. Agriculture has played an important role in the country's development as a major source of income, food, raw materials, employment and 
Saada Abba Abdullahi.

Estimating the Determinants of Food Import Demand in Africa

foreign exchange earnings (Adeniyi and Adeyemo, 2014 and Abdullahi, 2014). Prior to the 1970's, the agricultural sector provides 60 percent of Nigeria's GDP, $95 \%$ of its food needs and $70 \%$ of export earnings through exportation of six major items which are groundnut, cotton, rubber, cocoa, palm oil and palm kernel. During this period, agriculture provides enough food that sustained the economy and this continued until the oil boom in 1970. The huge revenue from oil led to the neglect of agriculture which led to decline in its productivity, then turns Nigeria into a net importer of food and an oil dependent economy.

Today, crude oil revenue accounts for $75 \%$ of Nigeria's GDP while the revenue from the non-oil sector including agriculture account for only $25 \%$ or less annually (CBN, 2018). Despite the huge revenue generated from the oil sector, statistical estimates indicate that about $70 \%$ of the population in Nigeria lives on less than US $\$ 1.25$ per day and the country is characterized by threat of hunger which in 2012 ranked it the 40th out of 79 on the Global Hunger Index and in 2011 the 156th out of 187 on the UNDP Human Development Index (FSP, 2019). The World Bank (2007) reported that about $35 \%$ to $40 \%$ of the population in Nigeria suffers from food insecurity. The government of Nigeria has adopted food imports as a short-term measure to meet domestic demand which was later dropped due to high food import bills (Adeniyi and Adeyemo, 2014). Between 1990 and 2011, the estimated food import bills in Nigeria were about 1.0 billion per day which is equivalent to about US $\$ 9.28$ million worth of food per day in the period (Olusoji et al 2014). The major drivers of the high level of food importation in Nigeria were rapid increase in population growth, urbanization and decline in agricultural productivity. FAO (2019) reported that for over 20 years, the value-added per capital increase by less than $1 \%$ annually in Nigeria's agriculture which indicates that the country lost USD 10 billion in its annual export of its major agricultural commodities due to decline in their production. To overcome these problems, the government introduced various programmes and measures to reform the agricultural sector and diversify the economy to boost domestic production, reduce food import and improve food security in Nigeria. However, the food production pace has still not met the domestic food demand in Nigeria.

Many studies have investigated the determinants of import demand in Nigeria (see Olayide, 1968; Ozo-Eson, 1984; Ajayi, 1975; Obadan, 1986; Egwaikhide, 1999; Suleiman and Abdullahi, 2012; Omoke, 2012; Omotor, 2014 and Ogbonna, 2016) among others. However, there are few studies on determinants of food import demand in Nigeria with focus on rice importation (see, Onu et al, 2015; Adeniyi and Adeyemo, 2014, Olusoji et al, 2014; Grace, 2010). Most of the studies on food import demand on selected items focused on Asia and advanced countries (see, Melo et al, 2015, Alnafissa and Alderiny, 2019; Cheng et al, 2015; Baiyegunhi and Sikhosana, 2012; Yazici, 2012; 
Safoulanitou and Ndinga, 2010).

The purpose of this paper is to examine the determinants of food import demand in Nigeria over the period 1981 to 2019. The motivation for this study is that understanding the factors that affects food import demand is important for effective policy decision that will help to improve food security, curb hunger and reduce food import in Nigeria. Melo et al (2015) showed that high response of food import demand to income shows that income-oriented policy is the best in controlling measure of food demand and undernutrition, while a low response indicates that other policy intervention would be more effective because increase in income will have limited effect on food demand. Yazici (2015) also pointed out that understanding the trade elasticities can help to assess the impact of policies on price and/or income in a country. The paper contributes to the literature is the following ways: first, it provides the elasticities estimates on food import demand in contrast to a majority of the previous studies that concentrated on aggregated import or rice import demand in Nigeria (for these studies see section 2). To my knowledge this is one of the first studies conducted on aggregated food import demand in Nigeria. Second, the paper employs the ARDL bounds testing approach to investigate both the long- and the short-run elasticities, unlike the previous studies that used the regression analysis and/or Johansen cointegrated model. The ARDL model has certain merits over the Johansen (1981) cointegration models: i) it can be use to estimate relationship between variables that are of different order of integration ii) it simultaneously estimates both the short-run and long-run parameters of the model (Yazici, 2015) iii) it provides better estimates especially when dealing with small sample (Mah, 2002).

The paper is structured as follows: section 2 reviews the relevant empirical studies on food import demand. Section 3 discusses the methodology and data for the study. Section 4 presents the empirical results and discussion. Section 5 concludes and summarizes and offers recommendations from the main findings of the research.

\section{Literature Review}

The modern international trade theories that explained the determinants of export and import demand are the theory of comparative advantage, the Keynesian trade multiplier, and new trade theory (or, the imperfect competition theory of trade). Each of these theories explained the influence of price and income in determining international trade. However, the empirical studies on the import demand function are based on the imperfect substitutes model proposed by Goldstein and Khan (1985). The model assumes that import demand is determined by real income, import price in local currency and price index for domestically produced goods. Since then this model or 
Saada Abba Abdullahi.

Estimating the Determinants of Food Import Demand in Africa

its modification has been employed to estimate the import demand function in different countries using empirical analysis.

In the case of Nigeria there is a large number of literature that investigated the import demand using this model which includes; Olayide (1968), Ozo-Eson (1984), Ajayi (1975), Obadan (1986), Egwaikhide (1999), Suleiman and Abdullahi (2012), Omoke (2012), Omotor (2014) and Ogbonna (2016) among others. These studies examined the aggregate import demand in Nigeria using different methodology, data sets and variables in their analysis. However, there are little studies on food import demand of some selected food items which majority focused on rice import in Nigeria. Onu et al (2015) examined the trend in Nigeria's rice production and imports over the period 1980 to 2013 using the exponential trend equation models. They found that the quantity of rice production and the quantity of imported rice exhibited significant growth and time trend variable is the major factor in determining both the production and import of rice during the study period. The results suggest that price and nonprice factors should be considered when making policies of reducing rice imports in Nigeria in both the short and long terms. Adeniyi and Adeyemo (2014) investigate the determinants of total food imports and trend of some selected food items (sugar, rice and wheat) in Nigeria over the period 1981 to 2010 using the regression analysis. They found that the determinants of food import which are income, relative price, domestic food production, external reserves, exchange rate and population were all significant in explaining the changes in the quantity of the three selected food imports over the study period. Olusoji et al (2014) analyse the food import structure and bills in Nigeria over the period 1990 to 2010 using the review analysis. They found that the food import bills in the Nigeria were about 1.0billion per day which is equivalent to about USD\$9.28million worth of food per day between 1990 and 2011. They found that the major food items imported are wheat, rice, sugar, fish and milk which account more than $84 \%$ of the total import bills in Nigeria during the study period. Grace (2010) investigates the how changes in policy and economic growth affects Nigeria's rice import demand using the Generalized Least Squares over the period of 1972-2005. He found that real GDP, import price, urbanization area significantly explains import demand of rice. The result also shows that subsidy removal policy influences rice import demand while the rice import policy under the Structural Adjustment Programme (SAP) has insignificant impact on rice import in Nigeria. Nkang et al (2006) using the cointegration and error correction model investigated rice import in Nigeria over the period 1970-2002. They found that there is a long run relationship between rice import and domestic rice production, exchange rate, population, external reserves, import price, real GDP, total imports value and dummy for SAP in Nigeria. The result of the short run analysis indicates that changes in domestic rice production, total imports 
value and level of external reserves influences rice import.

Studies on food import demand in other countries includes Melo et al (2015) using the Meta regression analysis investigate the income elasticities of food demand in some selected African countries over the period 1990 to 2006. The results of the analysis conducted in forty-eight out of 54 African countries indicate income elasticities are higher in demand of food that constitute more diet like protein and vegetables in majority of the countries. The author also found that countries with higher level of income have lower elasticities of food demand and calories, while the elasticities of demand for nutrients are higher. Furthermore, the result shows that the income elasticities of food demand in countries with a larger percentage of urban population is lower compared to those with population concentrated in the rural areas. The study concludes that food income elasticities across African countries differ by region. Alnafissa and Alderiny (2019) examine the import demand of natural honey in Saudi Arabia from Pakistan, Australia, Yemen, Mexico, Argentina, and Germany over the periods 1991 to 2017. Using AIDS model, the results shows that the own-price elasticities of import demand for natural honey were negative and significant in all the countries except from Pakistan while in Yemen their demand for imported honey is price inelastic. Cheng et al (2015) investigate the determinants of meat import in China and found that price and real GDP are the most important determinant of China's import demand while tariffs show insignificant effect. The result indicates that increase in the real GDP and consumption capacity increases will increase China's potential on meat imports demands. Yazici (2012) examined the import and export demand functions of Turkish agricultural using the ARDL bounds test over the period 1970-2003. The result shows that relative price has significant influence on import demand in both the short-run and long-run while domestic income is insignificant. However, their nominal effective exchange rate shows significant impact in determining Turkish agricultural import in the long-run over the study period. Baiyegunhi and Sikhosana (2012) analyse the determinants of Wheat import demand in South Africa over the period 1971 to 2007. They found that real gross domestic product; import price; domestic wheat production level and the price of sugar cane are significant in explaining quantity of South Africa's wheat during the study period. Safoulanitou and Ndinga (2010) using the Johansen cointegration test investigate the determinants of Congo's food import demand. They found that income, exchange rate of the local currency, the domestic production, re-export trade and armed conflicts all significantly influence food importation in both the short and/or long term. The authors show that massive food imports in Congo's is a strategy used by the country to increase its food security and also to export food products to countries like Angola and DRC. Uzunozi and Akcay (2009) applied the double logarithmic-linear function to examine the determinant of Wheat import demand in Turkey over the period 1984- 
Saada Abba Abdullahi.

Estimating the Determinants of Food Import Demand in Africa

2006. They result indicates that income per capital, exchange rate, domestic demand, level of wheat production and trend factors are significant in explaining wheat import in the country. They also found that wheat import demand can be strongly affected by changes in domestic wheat prices which will over time gradually the make consumers to buy more of domestic wheat than imported wheat in Turkey.

\section{Material and Methods}

\subsection{Model}

This paper adopted the traditional import demand function which considers the quantity demand of food import to be function of its major determinants i.e price and income. The model can be specified as follows:

$$
Q f_{t}=f(p, y)
$$

The model can be specified in log-linear form as:

$$
L f_{t}=\beta_{0}+\beta_{1} L p_{t}+\beta_{2} L y_{t}+\varepsilon_{t}
$$

where $f$ is the quantity demand of food import, $p$ the food import price and $y$ the real GDP. The coefficients $\beta_{1}$ and $\beta_{2}$ are of the price and income elasticities estimates, respectively. According to economic theory, the coefficient $\beta_{1}$ ' should be negative because increase in price will decrease food import demand while $\beta_{2}$ should be positive because the import demand of food is expected to increase with increase in income. Based on equation (1) the model to be estimated in this study can be specify as:

$$
L f_{t}=\beta_{0}+\beta_{1} L p_{t}+\beta_{2} L y_{t}+\beta_{3} L f p_{t}+\beta_{4} L p o p_{t}+\beta_{5} L e x g_{t}+\varepsilon_{t}
$$

where $f$ is the quantity of food import, $p$ is food import price, $y$ is real GDP, $f p$ is food production, pop is population and exg is the exchange rate. The coefficients $\beta_{1}$ to $\beta_{5}$ are the elasticities while $\varepsilon_{t}$ is the error term.

The Pesearan et al (2001) ARDL bounds testing approach will be used to examine the long run cointegration relationship between the variables and their elasticities. The long run specification of the model is as follows:

$$
\begin{gathered}
\Delta L f_{t}=\beta_{0}+\sum_{t-\mathrm{i}}^{k} \beta_{1} \Delta L p_{t}+\sum_{t-\mathrm{i}}^{k} \beta_{2} \Delta L y_{t}+\sum_{t-\mathrm{i}}^{k} \beta_{3} \Delta L f p_{t}+\sum_{t-\mathrm{i}}^{k} \beta_{4} \Delta L p o p_{t}+\sum_{t-\mathrm{i}}^{k} \beta_{5} \Delta L \operatorname{exg} g_{t}+\alpha_{1} f_{t-i}+\alpha_{2} p_{t-i}+ \\
+\alpha_{4} f p_{t-i}+\alpha_{5} \text { pop }_{t-i}+\alpha_{6} \operatorname{exg}_{t-i}+\varepsilon_{t}
\end{gathered}
$$

Equation (3) test the hypothesis $H_{0}: \alpha_{1}=\alpha_{2}=\alpha_{3}=\alpha_{4}=\alpha_{5}=\alpha_{6}=0$, there is no cointegration relationship between the quantity of food import 
(f) and the selected independent variables against the alternative hypothesis $H_{0}: \alpha_{1} \neq \alpha_{2} \neq \alpha_{3} \neq \alpha_{4} \neq \alpha_{5} \neq \alpha_{6} \neq 0$ using the bounds testing procedure. The ARDL model is a two- step testing procedure where we first select the best optimal lag length for the model selected and then the F-test is employed to provide the upper and lower bounds critical values. The decision rule of the test is that we reject the null hypothesis of no cointegration when the F-statistic has higher value than the upper bounds. In the second step, when there exists a long run cointegration, the conditional ARDL model is then estimated using the ordinary least square method (OLS) determined by a certain information criterion. The error correction model can then be used to establish the short-term relationship and elasticities. The short run specification of the model is as follows:

$$
\begin{aligned}
\Delta L f_{t}=\beta_{0}+\sum_{t-\mathrm{i}}^{k} \beta_{1} \Delta L p_{t}+\sum_{t-\mathrm{i}}^{k} \beta_{2} \Delta L y_{t}+\sum_{t-\mathrm{i}}^{k} \beta_{3} \Delta L f p_{t}+\sum_{t-\mathrm{i}}^{k} \beta_{4} \Delta L p o p_{t}+ \\
+\sum_{t-\mathrm{i}}^{k} \beta_{5} \Delta \operatorname{Lexg}_{t}+\delta E C T_{t-1}+\varepsilon_{t}
\end{aligned}
$$

where, $\varepsilon_{t}$ represent the residual and $\delta$ is the coefficient for the error correction model which measure the speed of convergence of the variables to the long run equilibrium position. In theory, the coefficient $\delta$ is expected to be statistically significant and negative for short run convergence to take place.

\subsection{Data and its properties}

The data used consist of annual time series for total food import (FI), food import price (proxied by consumer price index) $(\mathrm{P})$, real gross domestic product $(\mathrm{Y})$, total food production (FP) population rate (POP), exchange rate $(\mathrm{EXG})$ of Nigeria over the period 1981 to 2019. The data on real GDP was sourced from Central Bank of Nigeria Statistical Bulletin (2019) while other variables were sourced from National Bureau of Statistics (2019). Food import is the value of import of all food items including live animals in Nigeria. The study period was selected based on the availability of data. All the variables were transformed into natural logarithm form for possible interpretation of the coefficients into elasticities (Ziramba, 2010).

Table 1

Summary statistics of the series

\begin{tabular}{lllllll}
\hline & LFI & LP & LY & LPOP & LFP & LEXG \\
\hline Mean & 10.9948 & 3.01837 & 8.71619 & 18.6182 & 15.4656 & 3.57048 \\
Median & 11.594 & 3.36331 & 8.70788 & 18.6141 & 15.2039 & 4.61196 \\
Maximum & 14.8752 & 8.05163 & 18.6657 & 19.0931 & 16.5747 & 5.72685 \\
Minimum & 6.68698 & -0.7056 & 4.97557 & 18.1427 & 14.3803 & -0.5108
\end{tabular}


Saada Abba Abdullahi.

Estimating the Determinants of Food Import Demand in Africa

\begin{tabular}{lllllll} 
Std. Dev. & 2.61506 & 2.36706 & 2.8139 & 0.28694 & 0.74338 & 1.99834 \\
Skewness & -0.2832 & 0.17299 & 0.93289 & 0.02946 & 0.13585 & -0.9301 \\
Kurtosis & 1.6773 & 2.52858 & 5.10717 & 1.82316 & 1.4896 & 2.42551 \\
Jarque-Bera & 3.27794 & 0.5414 & 12.5421 & 2.19834 & 3.72898 & 6.00109 \\
Prob & 0.19418 & 0.76284 & 0.00189 & 0.33315 & 0.15498 & 0.04976 \\
\hline
\end{tabular}

Note: $* *$ indicate significant at $5 \%$ levels

Table 1 reports the summary statistics of the time series variables used in the empirical analysis. The results show that all the series except food import and exchange rate exhibits positive skewness and their kurtosis is less than 3 except for real income which implies that they are platykurtic. The Jarque-Bera test shows that all the variables except income are normally distributed. Figure 1 plots the natural log values of each series used in this study. The plot illustrates that all the series show upward trend over the study period.

LFI

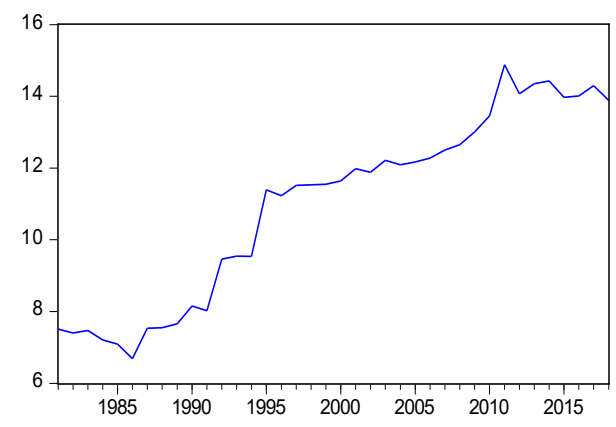

LY

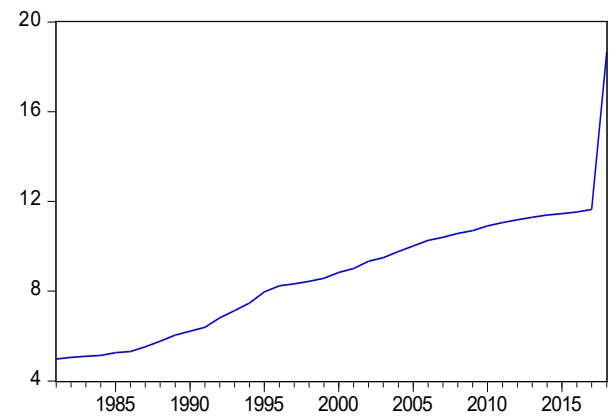

LP

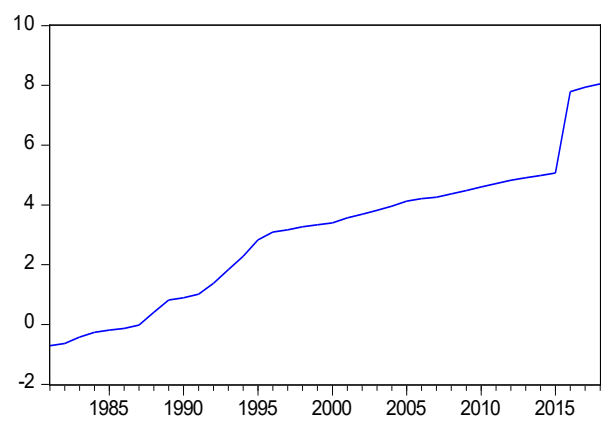

LPOP

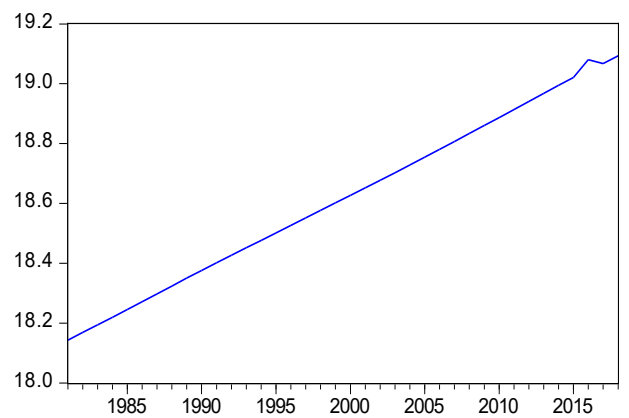


LFP

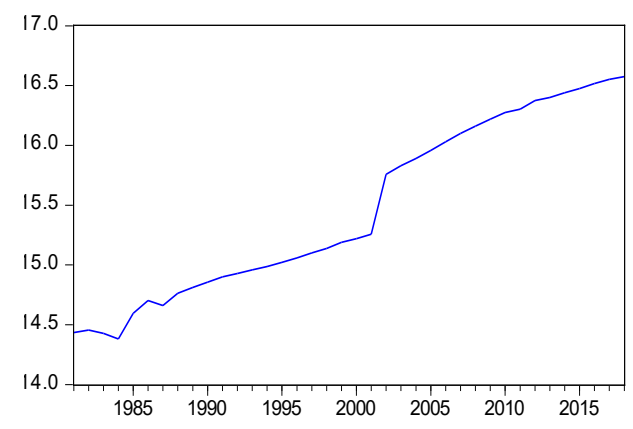

LEXG

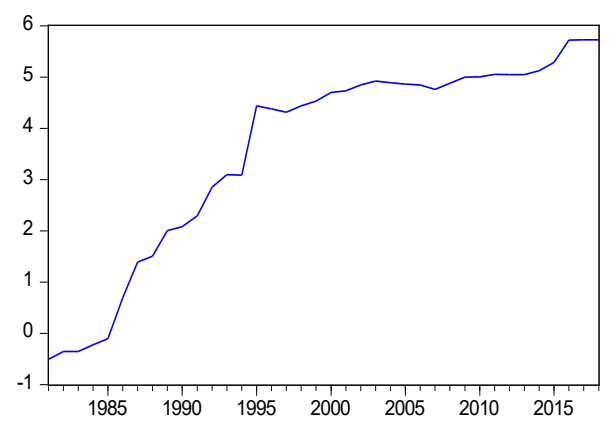

Figure 1: Plot of the series in natural logarithm form

\section{Result and Discussion}

\subsection{Unit root test}

Before applying the cointegration test to estimate the food import demand model, the order of integration of the variables is investigated first. The Augmented Dickey Fuller (ADF) (1981) unit root test is applied to examine the properties of the time series variables. Table 2 reported the result of the unit root test carried out with intercept and trend specification. The result shows that all the variables contain a unit root at level and therefore are non-stationary. This implies that we cannot reject the null hypothesis of the unit root test at $1 \%$ significance level. However, the result of the unit root test for the first differences shows that all the variables except real income and population are stationary at 5\% significance level. Since the variables have different order of integration, the ARDL bounds test is used to estimate the food import demand model in Nigeria.

\section{Unit root test}

\section{Table 2}

\begin{tabular}{lcc}
\hline Variables & \multicolumn{1}{c}{ Levels } & First difference \\
\hline LFI & $-2.0803(-3.5366)$ & $-7.5841 *(-3.5403)$ \\
LY & $-2.4079(-3.5366)$ & $-0.72392(-3.5403)$ \\
LP & $-1.7733(-3.5366)$ & $-5.9012 *(-3.5403)$ \\
LFP & $-2.1532(-3.5366)$ & $-5.79250 *(-3.5403)$ \\
LEXG & $-1.12563(-3.5366)$ & $-6.28936 *(-3.5404)$ \\
LPOP & $2.58472(-354428)$ & $0.82989(-3.5578)$ \\
\hline
\end{tabular}

Note: * denotes rejection of a unit root null hypothesis based on MacKinnon's critical value at 5\% level. The values in parentheses of the t-statistics are the level and difference critical at $5 \%$ level. 
Saada Abba Abdullahi.

Estimating the Determinants of Food Import Demand in Africa

\subsection{Cointegration and VECM tests}

Tables 3 reported both the short run and long run estimates of the food import demand model using the ARDL approach. The ARDL model is estimated with restricted constant using $(4,0,4)$ selected based on the Schwarz Information Criterion (AIC). Panel A shows the short run elasticity estimates while the result in panel B reported the long run elasticities of the food import demand model. The result of the short run model indicates that the coefficient of the ECT is negative and statistically significant at $5 \%$ significance level. The value of the adjustment coefficient is -1.314 which implies that about $1.314 \%$ of the disequilibrium errors in the previous period can converge quickly to form a long run equilibrium in the current period. The result of the estimated elasticities indicate that the current and lag coefficients of the independent variables have the expected signs and are statistically significant except two-period and oneperiod lag coefficients of price and income, respectively. The estimates of the short run price and income elasticities are -7.41 and 10.79 , respectively. This implies that a $1 \%$ increase in price will decrease food import demand by $7.41 \%$, while increase in income will increase food import demand by $10.79 \%$ in the short run. Therefore, the short run price and income elasticities are elastic because food import demand response to small changes in price and income.

Furthermore, the short run estimated elasticities of other variables food production, population rate and exchange rate have the expected signs and are elastic with the values $-6.69,573.6,-1.18$, respectively. The result implies that these variables are important in determining short run food import demand behaviour in Nigeria. The diagnostic tests indicate the absence of serial correlation and hetero skedasticity in the residuals of the model at 5\% significance level which confirms the fitness of the model. The result of the Jarque-Bera normality test also indicates that the residuals are not normally distributed.

Table 3

Short run Estimates and Diagnostic test (Dependent variable D(FI))

\begin{tabular}{lccc}
\hline \multicolumn{1}{c}{ Variable } & Coefficient & Std. Error & t-Statistic \\
\hline D(LFI(-1)) & 0.652885 & 0.135043 & 4.83465 \\
D(LFI(-2)) & 0.169872 & 0.103725 & 1.63772 \\
D(LFP) & -6.698566 & 0.671802 & -9.971 \\
D(LFP(-1)) & 7.777911 & 0.937564 & 8.29587 \\
D(LFP(-2)) & 5.705782 & 0.726273 & 7.85625 \\
D(LP) & -7.149012 & 0.750589 & -9.5245
\end{tabular}




\begin{tabular}{|c|c|c|c|}
\hline $\mathrm{D}(\mathrm{LP}(-1))$ & 6.632823 & 0.908842 & 7.29811 \\
\hline $\mathrm{D}(\mathrm{LP}(-2))$ & -0.66681 & 0.521158 & -1.2795 \\
\hline $\mathrm{D}(\mathrm{LP}(-3))$ & 2.32457 & 0.592363 & 3.92423 \\
\hline $\mathrm{D}(\mathrm{LPOP})$ & 573.684005 & 61.34858 & 9.35122 \\
\hline D(LPOP(-1)) & 578.556333 & 60.714722 & 9.5291 \\
\hline D(LPOP(-2)) & -1098.938328 & 109.33288 & -10.051 \\
\hline $\mathrm{D}(\mathrm{LY})$ & 10.791652 & 0.992478 & 10.8734 \\
\hline $\mathrm{D}(\mathrm{LY}(-1))$ & -0.236172 & 0.635247 & -0.3718 \\
\hline $\mathrm{D}(\mathrm{LY}(-2))$ & -5.285948 & 0.842854 & -6.2715 \\
\hline $\mathrm{D}(\mathrm{LY}(-3))$ & 5.66373 & 0.663708 & 8.53347 \\
\hline $\mathrm{D}(\mathrm{LEXG})$ & -1.180908 & 0.231654 & -5.0977 \\
\hline $\mathrm{D}(\mathrm{LEXG}(-1))$ & -1.535984 & 0.237346 & -6.4715 \\
\hline $\mathrm{D}(\mathrm{LEXG}(-2))$ & 1.175965 & 0.202912 & 5.79544 \\
\hline $\mathrm{ECT}(-1)$ & -1.314087 & 0.122823 & -10.699 \\
\hline Daignostic tests & Value of statistics & P-value & \\
\hline Normality $^{1}$ & 0.9774 & 0.6134 & \\
\hline No serial correlation $^{2}$ & 1.9072 & 0.2285 & \\
\hline No heteroskedasticity ${ }^{3}$ & 0.8480 & 0.6501 & \\
\hline
\end{tabular}

Note: $* * * * * *$ indicate significant at $1 \%, 5 \%$ and $10 \%$ levels, respectively. 1 : Jarque-Bera normality test with $x^{2}$ distribution, 2: Breusch-Godfrey serial correlation LM test and 3: Breusch-pagan-Godfrey heteroskedasticity test. The upper bound critical value at $10 \%$ significance level is 3.00 less than F-statistic value of 9.41 Peseran et al. (2001).

The long run estimate of the food import demand model is reported in panel B, Table 3. The result indicates that all the independent variables have the expected signs except exchange rate and are statistically significant at 5\% significance level. The long run income and price elasticity are $5.57 \%$ and -4.57 , respectively. The estimate indicates that $1 \%$ increase in income will lead to $5.57 \%$ increase in food import demand while increase in price will reduce food import demand by $4.57 \%$ in the long run. The short run and long run income and price elasticities are both elastic. Therefore, food demand is a normal good in Nigeria. However, the result indicates that income has more effect on food import demand than price in both the short run and long run. 
Saada Abba Abdullahi.

Estimating the Determinants of Food Import Demand in Africa

Table 4

Long run Estimates (Dependent variable (FI))

\begin{tabular}{lclc}
\hline \multicolumn{1}{c}{ Variable } & Coefficient & Std. Error & t-Statistic \\
\hline LFP & -10.866024 & 2.142176 & $-5.072423^{*}$ \\
LP & -4.577345 & 1.64051 & $-2.790196^{*}$ \\
LPOP & 24.911988 & 5.811723 & $4.286506^{*}$ \\
LY & 5.574318 & 1.685312 & $3.307588^{*}$ \\
LEXG & -0.276834 & 0.482564 & -0.573674 \\
C & -321.208423 & 90.3801 & -3.553973 \\
\hline
\end{tabular}

Note: $*, * * * * *$ indicate significant at $1 \%, 5 \%$ and $10 \%$ levels, respectively

In the case of food production, the elasticity coefficient is negative -10.86 and significant which suggests that a $1 \%$ increase in domestic food production will reduce food import demand. The elasticity of the population coefficient is positive and statistically significant with value of 24.91 which implies that a $1 \%$ increase in population will induce larger change in quantity of food import. The result shows that the small increase in population will lead to large change in food import demand because domestic food production cannot meet consumer demand. Lastly, the exchange rate elasticity is negative but insignificant. The long run exchange rate elasticity is -0.27 , which means that change in exchange rate policy will exert no effect on food import demand in the long run. In sum, the result of the short and long run analysis indicates that both price and income are important determinants of food import demand and are elastic in Nigeria. The result also indicates that food production and population have strong influences on food import demand while exchange rate has no effect on food import demand in the long run.

\section{Conclusion}

This paper investigates the determinants of food import demand in Nigeria using the ARDL cointegration bounds testing approach. The paper used annual time series data over the period 1981 to 2019. The estimated result indicates that both the short run and long run price and income elasticities are significantly negative and positive, respectively. The result indicates that the short run and long run price and income elasticities are greater than unity, they are both elastic. The result further shows that while population and food production exert significant influence in determining food import demand in both the short run and long run exchange rate is insignificant in the 
long run.

The policy implication of the findings is as follows: that the estimate of the long run elasticity suggests that food import demand is price and income elastic in Nigeria. The result suggests that both price and income-oriented policies will be effective in controlling food import without affecting economic activities. There is need to implement strong policies and strategies that will boost domestic food production because it will reduce food import demand and curb food insecurity. Finally, trade policies such as increase charges and banning of import of selected food items will help improve local food production which will reduce food import demand in the Nigeria.

\section{Reference}

1. Abdullahi, S. A. (2014). Investigating the Relationship between World Crude Oil Price and Food Prices in Nigeria, Yobe Journal of Economics, Yobe State University, $1,116-122$.

2. Adeniyi, O. R. \& Adeyemo, B.A. (2014). A Review of Trends in Import of Some Selected Foods in Nigeria (1981-2010): Matters Arising, Natural Resources, 5, 367-374.

3. Ajayi, S. I. (1975). An Econometric Analysis of Import Demand in Nigeria, Nigerian Journal of Economic and Social Studies, 17, 169-182.

4. Alnafissa, M \& Mahmoud, A. M. (2019). Analysis of Saudi demand for imported honey using an Almost Ideal Demand System (AIDS), Journal of the Saudi Society of Agricultural Sciences https://doi.org/10.1016/j.jssas.2019.05.001

5. Baiyegunhi, L. J \& Sikhosana, A. M. (2012). An estimation of import demand function for wheat in South Africa: 1971-2007, African Journal of Agricultural Research, 37, 5175-5180, 25

6. CBN (2018). Central Bank of Nigeria Data Base. Retrieved on November 20, 2019 https://www.cbn.gov.ng/documents/data.asp

7. CBN (2007). Central Bank of Nigeria Statistical Bulletin 2007. Retrieved on November 20, 2019 https://www.cbn.gov.ng/documents/data.asp.

8. Cheng, Y-H, Gao, Z \& Jr, S. J. (2015). Changing structure of China's meat imports, Journal of Integrative Agriculture, 6,1081-1091.

9. Dickey, D. A. \& Fuller, W.A. (1981). Likelihood ratio statistics for autoregressive time series with a unit root, Econometrica, 49,1057-1072.

10. Egwaikhide, F. O. (1999). Determinants of imports in Nigeria: A dynamic specification, African Economic Research Consortium (AERC), 91,1-33.

11. FAO (2019). Food and Agriculture Organisation Data Base Retrieved on October 21, 2019 http://www.fao.org/faostat/en/\#data/TI 
Saada Abba Abdullahi.

Estimating the Determinants of Food Import Demand in Africa

12. FSP (2018) Food security portal supported by European commission country. Country resources. http://www.foodsecurityportal.org/nigeria/resources

13. Goldstein, M. \& Khan, M, (1985) Income and Price Effects in Foreign Trade. In Handbook of International Economics, 2 (Jones, R. and Kenen, P. Ed.). Amsterdam and New York, North-Holland, Elsevier, 1041-1105.

14. Grace, C.O. (2010). A Study of Increased Rice Import Demand in Nigeria: Measuring the Impact of Economic Growth and Changes in Policy, 農林業問題研究, 22-31

15. Johansen, S. (1988). Statistical Analysis of Cointegrating Vectors, Journal of Economic Dynamics and Control, 12, 231-254.

16. Mah, J. S. (2002). An Empirical Examination of the Disaggregated Import Demand of Korea - the Case of Information Technology Products, Journal of Asian Economics, 4, 237-244.

17. Melo, P., Abdul-Salam, Y., Roberts, D., Gilbert, A., Matthews, R., Colen, L., Mary, S., Gomez Y \& Paloma, S. (2015.) Income Elasticities of Food Demand in Africa: A Meta-Analysis; European Commission JRC technical report. doi:10.2791/661366

18. NBS (2019). Nigerian National Bureau of Statistics Data Base. Retrieved on October 21, $2019 \mathrm{http}: / /$ nigerianstat.gov.ng/elibrary?queries[search]=trade

19. Nkang, N. M, Abang, S. O, Akpan, O. E \& Edet, E. O. (2006). Rice production, imports and food security in Nigeria: An application of cointegration and error correction model, Journal of Food, Agriculture \& Environment, 1, 86-90.

20. Nteegah, A. \& Mansi, N. (2016). Analysis of Factors Influencing Import Demand in Nigeria, International Journal of Arts Humanities and Social Sciences (IJAHSS), 5, 67-75

21. Obadan, M. (1986). Elasticities in Nigeria's Import Trade, Benin Journal of Social Sciences, 2, 5 -19.

22. Ogbonna, C. B-B. (2016). Estimating Aggregate Import-Demand Function for Nigeria Revisited, Journal of Business and Management, 18, 64-72

23. Olayide, S. (1968). Import Demand Model: An Econometric Analysis of Nigeria's Import Trade, Nigerian Journal of Economic and Social Studies, 10, 303319.

24. Olusoji, V. I, Afolake, C, A, Olayemi, T, O \& Oladipo, A.A. (2014). An analysis of Nigeria food imports and bills, International Journal of Economics, Commerce and Management United Kingdom, 9, 1-10

25. Omotor, D.G. (2010). An Aggregate Import Demand Function for Nigeria. https://www.researchgate.net/publication/246044661

26. Omoke, C.P. Aggregate Import Demand and Expenditure Components in Nigeria. Mathematical and Quantative Methods, Economica, 8, 149-163 
27. Onu, D.O, Obike, K.C, Ebe, F.E \& Okpara, B.O. (2015). Empirical assessment of the trend in rice production and imports in Nigeria (1980 - 2013), International Research Journal of Agricultural Science and Soil Science, 6, 150-158

28. Ozo-Eson, P. I. (1984). Determinants of import demand in Nigeria: A monetary approach, The Nigeria Journal of Economic and Social Studies, 1, 73-83.

29. Peseran, M. H., Y. Shin \& R. J. Smith. (2001). Bounds Testing Approaches to the Analysis of Level Relationships, Journal of Applied Econometrics, 16, 289-326.

30. Safoulanitou, N.K \& Ndinga, A.M.M. (2010). An Empirical Analysis of the Determinants of Food Imports in Congo, African Economic Research Consortium, Nairobi. AERC Research Paper No. 195

31. Suleiman, H. H \& Abdullahi, S.A. (2008). Investigating the Long-Run Relationship between Nigerian Export and Import, Bayero Journal of Interdisciplinary Studies, 1, 152-159.

32. Uzunoz, M \& Akcay, Y. (2009). Factors affecting the import demand of wheat in Turkey, Bulgarian Journal of Agricultural Science, Agricultural Academy, 15, 6066.

33. Yazici, M. (2012). Turkish Agricultural Import and Export Demand Functions: Estimates from Bounds Testing Approach, Economic Research, 25, 1005-1016.

34. World Bank (2007). Rising food prices: Policy options and World Bank response. Retrieved on March 20, 2013 from http://siteresources.worldbank.org/ NEWS/Resources/ 